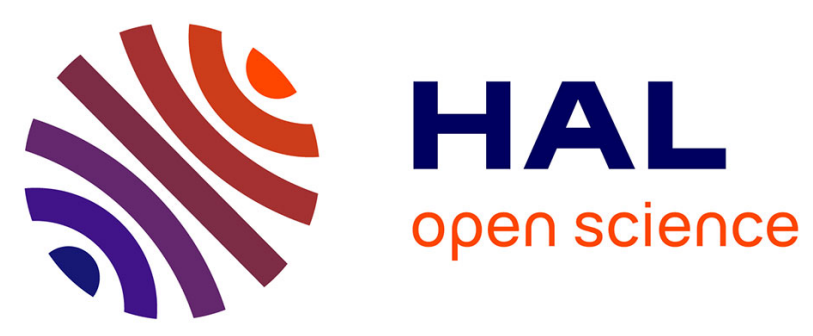

\title{
Travel-time tomography imaging the Ecuadorian subduction, north of the Mw 7.8 Pedernales earthquake
}

Alexandra Skrubej, A. Galvé, Mireille Laigle, Andreas Rietbrock, Philippe

Charvis, Sandro Vaca, Hans Agurto-Detzel, Laure Schenini, Felix

Bogelspacher, Davide Oregioni, et al.

\section{To cite this version:}

Alexandra Skrubej, A. Galvé, Mireille Laigle, Andreas Rietbrock, Philippe Charvis, et al.. Traveltime tomography imaging the Ecuadorian subduction, north of the $\mathrm{Mw} 7.8$ Pedernales earthquake. EGU General Assembly 2021, Apr 2021, Gather Online, Austria. 10.5194/egusphere-egu21-10959 . hal-03434467

\section{HAL Id: hal-03434467 https://hal.science/hal-03434467}

Submitted on 18 Nov 2021

HAL is a multi-disciplinary open access archive for the deposit and dissemination of scientific research documents, whether they are published or not. The documents may come from teaching and research institutions in France or abroad, or from public or private research centers.
L'archive ouverte pluridisciplinaire HAL, est destinée au dépôt et à la diffusion de documents scientifiques de niveau recherche, publiés ou non, émanant des établissements d'enseignement et de recherche français ou étrangers, des laboratoires publics ou privés. 
EGU21-10959, updated on 16 Jul 2021

https://doi.org/10.5194/egusphere-egu21-10959

EGU General Assembly 2021

(c) Author(s) 2021. This work is distributed under

the Creative Commons Attribution 4.0 License.

\title{
Travel-time tomography imaging the Ecuadorian subduction, north of the Mw 7.8 Pedernales earthquake
}

\author{
Alexandra Skrubej ${ }^{1}$, Audrey Galve ${ }^{1}$, Mireille Laigle ${ }^{1}$, Andreas Rietbrock ${ }^{2}$, Philippe Charvis ${ }^{1}$, Sandro \\ Vaca $^{3}$, Hans Agurto-Detzel ${ }^{1}$, Laure Schenini ${ }^{1}$, Felix Bogelspacher ${ }^{2}$, Davide Oregioni ${ }^{1}$, Damien \\ Vignon ${ }^{1}$, Andreas Brotzer ${ }^{2}$, Maria Muñoz Muñoz ${ }^{4}$, and Mayra Moreno Piña ${ }^{4}$ \\ ${ }^{1}$ Université Côte d'Azur, IRD, CNRS, Observatoire de la Côte d'Azur, Géoazur, 06560 Valbonne, FRANCE \\ (skrubej@geoazur.unice.fr) \\ ${ }^{2}$ Karlsruhe Institute of Technology, Geophysical Institute, Karlsruhe, 76187, Germany \\ ${ }^{3}$ Instituto Geofisico, Escuela Politécnica Nacional, Quito, 170525, Ecuador \\ ${ }^{4}$ Instituto Oceanográfico y Antártico de la Armada (INOCAR), Avenida 25 de Julio via Puerto Marıtimo, Base Naval Sur, \\ Guayaquil, Ecuador
}

The Ecuadorian subduction regularly hosts large earthquakes. Among them, the Mw 8.81906 earthquake is the 7th biggest known event. Following the recent $2016 \mathrm{Mw} 7.8$ Pedernales earthquake, a large deployment of onshore/offshore seismological stations, in addition to the permanent seismological/geodetical network, revealed a complex slip behavior including the presence of seismic and aseismic slip.

During the geophysical experiment HIPER, in march 2020, 47 Ocean Bottom Seismometers (OBS), were densely deployed along a 93-km-long trench-perpendicular profile, recording airgun shots (4990 cu.inch.) performed by R/V Atalante to obtain a high-resolution P-wave velocity image. The profile was located north of the 2016 Pedernales rupture zone passing through an area experiencing aseismic slip and a region of contrasted geodetic interseismic coupling.

We used the traveltime tomography code «tomo2d » (Korenaga et al., 2000) to invert first arrivals and reflected phases recorded by our OBS. A joint 2D-seismic-reflection profile was acquired (abstract by L. Schenini) and provides details on the oceanic basement topography and on Vp velocities in shallow sedimentary layers.

Regarding the structural complexity in the region, we decided to start the inversion using an a priori 2D velocity model. Several geophysical experiments have already been conducted offshoreonshore Ecuador (SISTEUR, 2000 ; SALIERI, 2001 and ESMERALDAS, 2005). Compilation of velocity models from tomographic images were used to build two a priori 1D Vp velocity models for both the Nazca oceanic crust and the forearc seismic structure. A 2D a priori Vp velocity model was built by merging the results of the two localized inversions using a selection of OBS on each side of the trench.

We obtain the crustal structure of the upper and subducting plates down to $20 \mathrm{~km}$ depth. Beneath the trench, a $\sim 30-\mathrm{km}$-wide low-Vp anomaly is observed at lithospheric scale. This velocity is $10 \%$ 
lower than the typical Vp values observed for hydrated Pacific-type oceanic crust near the trench (Grevemeyer et al., 2018). Recorded PmP phases will allow us to further constrain the crustal thickness. While we observe PmP phases in areas of low-Vp, the Moho reflectivity weakens and even disappears from the coincident MCS line. This intriguing observation could highlight processes, such as the presence of fluids or serpentinization, that need to be identified and better understood. 